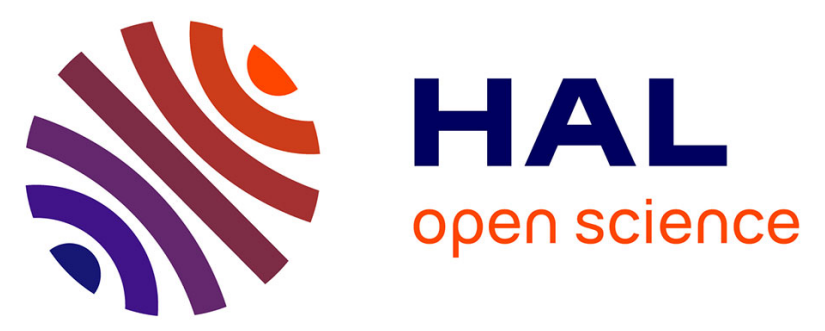

\title{
Sequence and regulation of European eel prolactin mRNA
}

\author{
B. Quérat, B. Cardinaud, A. Hardy, B Vidal, Gisela d'Angelo
}

\section{To cite this version:}

B. Quérat, B. Cardinaud, A. Hardy, B Vidal, Gisela d'Angelo. Sequence and regulation of European eel prolactin mRNA. Molecular and Cellular Endocrinology, 1994, 102 (1-2), pp.151-160. 10.1016/03037207(94)90108-2 . hal-03034067

\section{HAL Id: hal-03034067 \\ https://hal.science/hal-03034067}

Submitted on 9 Dec 2021

HAL is a multi-disciplinary open access archive for the deposit and dissemination of scientific research documents, whether they are published or not. The documents may come from teaching and research institutions in France or abroad, or from public or private research centers.
L'archive ouverte pluridisciplinaire HAL, est destinée au dépôt et à la diffusion de documents scientifiques de niveau recherche, publiés ou non, émanant des établissements d'enseignement et de recherche français ou étrangers, des laboratoires publics ou privés. 


\title{
Sequence and regulation of European eel prolactin mRNA
}

\author{
B. Quérat ${ }^{*, a}$, B. Cardinaud ${ }^{\text {b }}$, A. Hardy ${ }^{\text {a }}$, B. Vidal ${ }^{\text {a }}$, G. D’Angelo ${ }^{\text {a }}$ \\ a Laboratoire de Physiologie Générale et Comparée, MNHN, Unité Evolution des Régulations Endocriniennes, CNRS, 7 Rue Cuvier, \\ 75231 Paris Cedex 05, France \\ ${ }^{b}$ Institut Alfred Fessard, CNRS, 91198 Gif sur Yvette, France
}

(Received 26 November 1993; accepted 7 March 1994)

\begin{abstract}
cDNA clones encoding the European eel (Anguilla anguilla L.) prolactin were isolated from a pituitary cDNA library constructed in $\gamma \mathrm{gt10}$, using a rainbow trout Prl cDNA fragment as a probe. Four different inserts were subcloned into the pGEM $3 \mathrm{Z}$ plasmid after PCR amplification. The 1082 bp-long nucleotide sequence revealed an open reading frame of 627 bp encoding a 24 amino acid-long signal peptide followed by a 185 amino acid-long mature protein. Comparison studies showed $60-70 \%$ homology with other known teleost fish prolactins and 30-45\% with non-teleost fish, amphibian, reptilian, avian and mammalian prolactins. In situ hybridization studies using labelled prolactin RNA probe showed a strong signal in the rostral pars distalis of the pituitary gland. We next examined the physiological regulation of this prolactin synthesis in vivo using Northern blot analysis and prolactin cDNA probe labelled by random priming. The pituitary prolactin mRNA level was markedly decreased 3 weeks after transfer of eels from freshwater to sea water. Implants of thyroid hormones left for up to three weeks were ineffective on prolactin mRNA. Estradiol administered as implant, alone or in combination with $500 \mu \mathrm{g}$ testosterone, was also unable to significantly alter the pituitary mRNA level for prolactin in the freshwater silver eels whatever the dose used (20-500 $\mu \mathrm{g})$ and whatever the duration of treatment (from 4 days to 10 weeks).
\end{abstract}

Key words: Prolactin; Osmoregulation (Eel)

\section{Introduction}

Prolactin is a pituitary polypeptide hormone belonging to a family of hormones that includes growth hormone and placental lactogen (Nicoll et al., 1986), and the newly discovered somatolactin (Ono et al., 1990; Rand-Weaver et al., 1991). The close structural relationships between these hormones has led to the assumption that they have evolved from a common ancestral gene. The primary structure of prolactin has been characterized in all vertebrates classes. In teleosts, the amino acid sequence of prolactin has been determined in different species of tilapias (Yamagushi et al., 1988; Rentier-Delrue et al., 1989), salmonids (Yasuda et al., 1986; Song et al., 1988; Mercier et al., 1989), cyprinids (Yasuda et al., 1987; Chao et al., 1988; Chang et al., 1992), and in the catfish (Watanabe et al., 1992). In tilapias, two different forms of prolactin, a $20 \mathrm{kDa}$

\footnotetext{
* Corresponding author. Tel.: 331407936 20; Fax: 33140793618.
}

and a $24 \mathrm{kDa}$ proteins have been identified, each showing substantial differences in their amino acid sequences. These proteins are encoded by two distinct genes (Rentier-Delrue et al., 1989). In the Japanese eel, also, two different variants of prolactin were purified. Although these two forms were slightly different in amino acid composition, their partial amino acid sequences were identical (Suzuki et al., 1991) leaving the question of the number of genes encoding prolactin in the eel still open.

Prolactin is a pituitary hormone involved in a wide variety of functions in fish, such as osmoregulation, reproduction, growth and development (Clarke and Bern, 1980). The best documented of these functions, and certainly the most important one, is osmoregulation (Hirano, 1986). If several different functions are indeed fulfilled by prolactin in a given species, its expression and secretion should be subjected to multifactorial regulation. Owing to its original biological cycle, the eel could be an interesting model for the study of these regulations. A first metamorphosis, oc- 
curring in sea water, transforms the leptocephali (eel larvae) into young (glass) eels, allowing them to invade the continental fresh or brackish waters. Then, after a growth phase, the eels (the yellow stage eels) are subjected to a second metamorphosis that pre-accommodate them (then at the silver stage) to sea water and to their reproductive migration.

In this paper, we describe the cloning of the European eel prolactin and a preliminary study of the potential effects of some factors on the steady-state prolactin mRNA levels: the salinity of the water as a factor affecting the osmoregulation; thyroid hormones, as hormones involved in development; and finally, estradiol and testosterone as hormones of reproduction.

\section{Materials and methods}

\subsection{Prolactin $m R N A$ cloning and sequencing}

Isolation of mRNA and construction of the eel (Anguilla anguilla L.) pituitary cDNA library in $\gamma \mathrm{gt} 10$ vector have been previously described (Quérat et al., 1990). A rainbow trout prolactin cDNA fragment of 740 bp encompassing the coding region, kindly provided by Dr F. Rentier Delerue, was used as a probe for library screening. 25000 pfu were screened according to methods previously described (Quérat et al., 1990). Four recombinant phages were purified by the plate lysate method (Sambrook et al., 1989) and the inserts were amplified by PCR using primers corresponding to sequences flanking the cloning EcoRI site of the phage. The complete inserts or their HindIII restricted fragments were then subcloned in pGEM $3 Z$ vector (Promega Biotech). Sequences were determined using the Sequenase 2.0 sequencing system (USB) after alkali denaturation. Sequence analysis and comparisons were performed using the CITI2 programs (Dessen et al., 1990).

\subsection{In situ hybridization}

Two freshwater female silver eels were anaesthetized in MS 222 (Sandoz) and perfused intracardiacally for $5 \mathrm{~min}$ with $2 \%$ paraformaldehyde (PFA) in $100 \mathrm{mM}$ phosphate-buffered saline (PBS). The pituitary was removed with the attached brain, rinsed in $2 \%$ PFA, $100 \mathrm{mM}$ PBS, and placed in $20 \%(\mathrm{w} / \mathrm{v})$ sucrose, $100 \mathrm{mM}$ PBS, for $6 \mathrm{~h}$ at $4^{\circ} \mathrm{C}$. The tissue block was then frozen in isopentane cooled on dry ice. Serial sections of $15 \mu \mathrm{m}$ were cut using a Leitz cryostat, thaw-mounted onto gelatin-coated slides, and stored at $-20^{\circ} \mathrm{C}$ until hybridization. The anti-sense and sense labelled single-stranded RNA probes were synthesized using $\left[\alpha^{35}\right.$ S]UTP (> $1000 \mathrm{Ci} / \mathrm{mmol}$; Amersham) and
SP6 RNA polymerase (Promega Biotech) according to the manufacturer's recommendations from two linearized pGEM $3 \mathrm{Z}$ vectors containing a $500 \mu \mathrm{g}$ HindIII-Hin dIII fragment of the prolactin cDNA (encompassing the coding region) in both orientations. The sections were thawed at room temperature, fixed in $2 \%$ PFA, $100 \mathrm{mM}$ PBS for $15 \mathrm{~min}$, immediately rinsed twice in PBS and twice in $4 \times$ SSPE (SSPE: 0.18 $\mathrm{M} \mathrm{NaCl}, 10 \mathrm{mM}$ sodium phosphate, $\mathrm{pH} 7.7,1 \mathrm{mM} \mathrm{Na}{ }_{2}$ EDTA), $1 \times$ Denhardt's solution $(0.02 \%(w / v)$ Ficoll, $0.02 \%(\mathrm{w} / \mathrm{v})$ polyvinylpyrrolidone and $0.02 \%(\mathrm{w} / \mathrm{v})$ bovine serum albumin). Some sections were treated with RNAse A $\left(10 \mu \mathrm{g} / \mathrm{ml}\right.$ in $100 \mathrm{mM}$ PBS at $37^{\circ} \mathrm{C}$ for $30 \mathrm{~min}$ ) just after the postfixation in PFA. The sections were dehydrated through serial dilutions $(60-100 \%)$ of ethanol, delipidated in chloroform, partially rehydrated in $100 \%$ and $95 \%$ ethanol, and air-dried. $40 \mu 1$ of hybridization buffer ( $50 \%$ formamide, $4 \times$ SSPE, $1 \times$ Denhardt's solution, $1 \%$ sarkosyl, $10 \%$ dextran sulfate, $500 \mu \mathrm{g} / \mathrm{ml}$ yeast tRNA, $500 \mu \mathrm{g} / \mathrm{ml}$ calf thymus DNA, and $50 \mathrm{mM}$ dithiothreitol) containing $1 \times 10^{6} \mathrm{cpm}$ of labelled probe was distributed on each slide, and covered with a coverslip. Hybridization was carried out overnight at $46^{\circ} \mathrm{C}$. Following incubation, coverslips were removed in $2 \times$ SSPE, $20 \mathrm{mM} \beta$-mercaptoethanol. The slides were washed $2 \times 15 \mathrm{~min}$ in $1 \times$ SSPE, $20 \mathrm{mM}$ $\beta$-mercaptoethanol at $45^{\circ} \mathrm{C}$, treated with RNAse A (10 $\mu \mathrm{g} / \mathrm{ml}$ in $1 \times \mathrm{SSPE}$ at $37^{\circ} \mathrm{C}$ for $30 \mathrm{~min}$ ), and washed again $2 \times 15 \mathrm{~min}$ in $1 \times \mathrm{SSPE}, 20 \mathrm{mM} \beta$-mercaptoethanol at $45^{\circ} \mathrm{C}$. The sections were finally dehydrated through serial dilutions $(60-100 \%)$ of ethanol containing $0.3 \mathrm{M}$ ammonium acetate, air-dried, and covered with Hyperfilm beta-max X-ray film (Amersham) for 24 h. After development of the film, sections were dipped in Kodak NTB3 cmulsion (diluted 1:1 with $300 \mathrm{mM}$ ammonium acetate) and exposed for three days. The slides were then developed (Kodak D19), fixed and counterstained with hematoxylin and eosin, and examined using bright and dark-field microscopy.

\subsection{Treatments}

Freshwater female silver eels weighing 250-300 g were caught in ponds in Northern France and kept in tanks in running freshwater. Six eels were accommodated for 2 days in $50 \%$ artificial sea water (Wiegand GMBH)( 0.5 volume in freshwater) then transferred to full strength artificial sea water. The water was kept at $13-15^{\circ} \mathrm{C}$ in a closed system, filtered on charcoal, aerated, and renewed twice a week. For implantation, triiodothyronine and thyroxine (Sigma) were first dissolved in $\mathrm{NaOH} 0.1 \mathrm{~N}$ at a concentration of $40 \mu \mathrm{g} / \mathrm{ml}$ and then diluted in ethanol to $10 \mu \mathrm{g} / \mathrm{ml}$ and mixed with 10 volumes of coconut oil (Sigma) at $25^{\circ} \mathrm{C}$. The steroid hormones, testosterone and estradiol (Sigma), were directly dissolved in ethanol $(10-50 \mu \mathrm{g} / \mathrm{ml})$ be- 
fore being mixed with 10 volumes of coconut oil. One $\mathrm{ml}$ of hormone/ethanol/oil or ethanol/oil preparation (vehicle) was injected in the perivisceral cavity. The implanted eels were divided into groups depending on the nature of treatment and kept in separate tanks of running freshwater at $13-15^{\circ} \mathrm{C}$. Eels were killed by decapitation and the pituitary glands were immediatly collected, occasionally pooled, and kept in liquid nitrogen. Blood samples were collected in heparinized tubes and the plasma separated by centrifugation and kept at $-20^{\circ} \mathrm{C}$. Triiodothyronine and thyroxine, and testosterone and estradiol were radioimmunoassayed as previously described (Leloup and De Luze, 1980; Quérat et al., 1987).

\subsection{RNA extraction and Northern blot experiments.}

Total cytoplasmic RNA was extracted from individual or pools of two to four pituitary glands, quantified by measuring the absorbance at $260 \mathrm{~nm}$ and submitted to electrophoresis through a $1.2 \%(\mathrm{w} / \mathrm{v})$ agarose gel containing $6 \%$ formaldehyde as previously described (Quérat et al., 1991a). Transfer to nylon membranes (Hybond N, Amersham) was achieved by capillary blotting (Sambrook et al., 1989). Filters were baked for $2 \mathrm{~h}$ at $80^{\circ} \mathrm{C}$. Prehybridization, hybridization and washings were performed as previously described (Quérat et al., 1991a). The complete eel prolactin cDNA and a $1.5 \mathrm{~kb}$ rainbow trout $\beta$-actin cDNA fragment (kindly provided by $\operatorname{Pr}$ Y. Valotaire) were labelled using a Multiprime labelling system (Amersham) with $\left[\alpha^{32}\right.$ P]dCTP (3000 $\mathrm{Ci} / \mathrm{mmol}$; Amersham). Between two hybridization experiments, the blots were dehybridized by incubating 3 $\mathrm{h}$ in $15 \mathrm{mM} \mathrm{NaCl}, 1.5 \mathrm{mM}$ sodium citrate, $0.1 \%$ SDS at $75^{\circ} \mathrm{C}$. Signals on autoradiograms (Kodak X-OMAT films, Eastman Kodak) were quantified by scanning densitometry and the results for the prolactin mRNA level were corrected for recovery by dividing either by the actin mRNA level or by the amount of total RNA loaded into the gel. Statistical analysis was performed using Student's $t$-test.

\subsection{Southern blotting}

Preparation of genomic eel DNA, electrophoresis, transfer to nylon membranes (Hybond N, Amersham), hybridization and washing were performed as previously described (Quérat et al., 1990), using the complete eel prolactin cDNA labelled as for the Northern blot analysis.

\section{Results}

\subsection{Sequence determination and analysis}

Four different phage inserts were subcloned after PCR amplification using primers corresponding to se-

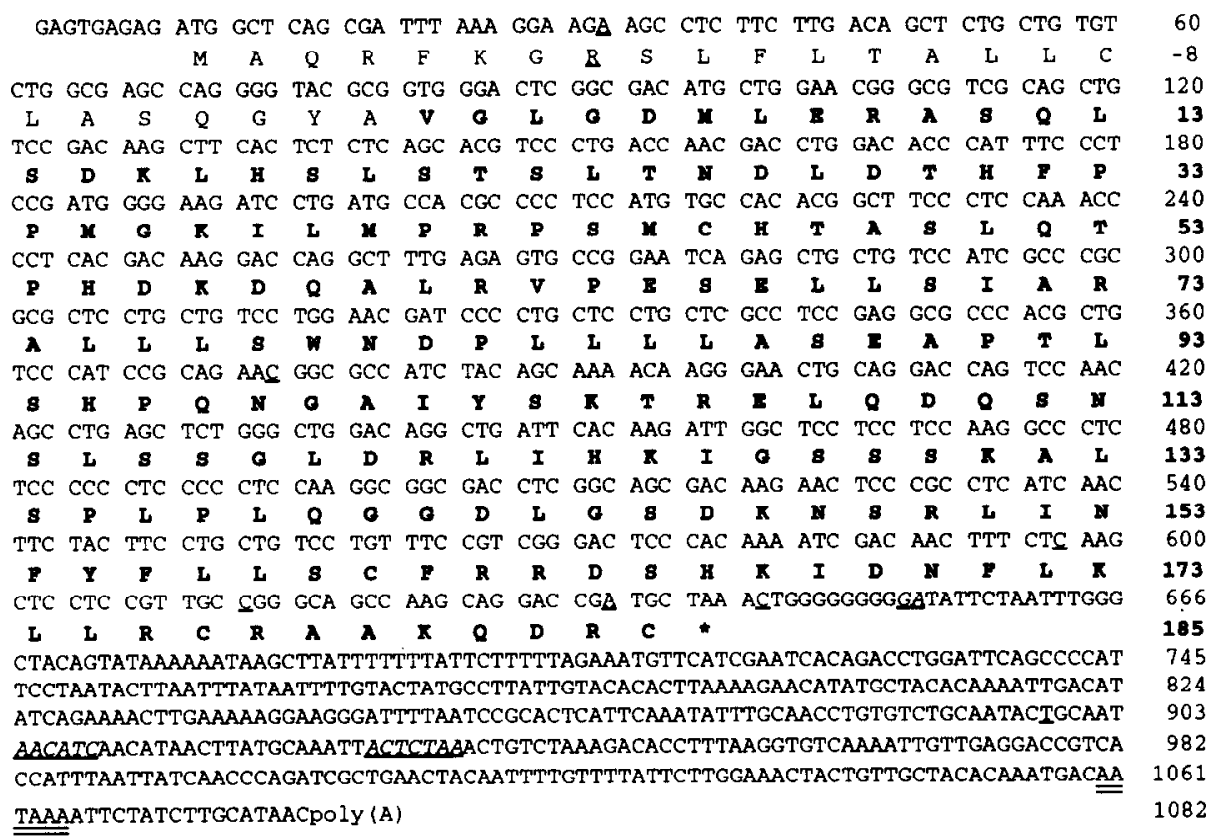

Fig. 1. Nucleotide and deduced amino acid sequences of the European eel prolactin. The presented nucleotide sequence was reconstructed from 4 different clones. The nucleotides that vary from one clone to another are underlined. Those that are absent in certain clones are indicated in italic. The modification of the nucleotide A (at position 33) to S, led to a change in the encoded amino acid $R$ ( -17 in the signal peptide) to S. The position of the cleavage site of the signal peptide was inferred from the partial amino acid sequence of the purified Japanese eel prolactin (Suzuki et al., 1991). The polyadenylation signal is twice underlined. 
quences flanking the EcoRI cloning site. The figure 1 represents the nucleotide and deduced amino acid sequence reconstructed from the partial sequences of the 4 phage inserts. Each part has been sequenced on at least two different phage inserts ( 3 for the coding region). Several differences were seen between the inserts; most of them concerned punctual, silent mutations. One led to the change of the arginine at the eighth position $(-17)$ of the signal peptide to a serine. Three segments of 2,5 and 7 nucleotides of the $3^{\prime}$ untranslated region were absent in one or several clones. The 4 inserts ended within 12 to 17 nucleotides following the polyadenylation signal AATAAA. Southern blot experiments showed only one signal when genomic DNA was restricted with BamHI $(25 \mathrm{~kb})$, $E c o R V(15 \mathrm{~kb}), E c o R I(9 \mathrm{~kb})$, and $B g l \mathrm{II}(7 \mathrm{~kb})$, and two signals when digested with Pst I ( 3.2 and $2.5 \mathrm{~kb})$, and HindIII ( 2.2 and $2.3 \mathrm{~kb}$ ), these two latter enzymes presenting 1 and 2 restriction sites in the full length cDNA respectively (data not shown).

The position of the cleavage of the signal peptide was inferred from the $\mathrm{N}$-terminal sequence of the Japanese eel prolactin (Suzuki et al., 1991). The sequence of the 185 amino acid-long mature protein was compared to other known prolactin sequences (Fig. 2). The eel prolactin shows a $60-70 \%$ homology score with other teleostean fish prolactins (except with the 177 amino acid-long tilapia prolactin), $42 \%$ with sturgeon prolactin, 33-36\% with lungfish, amphibian, reptilian and avian prolactins, and between $30-32 \%$ homology with mammalian prolactins.

\subsection{In situ hybridization}

Transversal sections of the pituitary gland show a strong signal in the anterior part when hybridized with

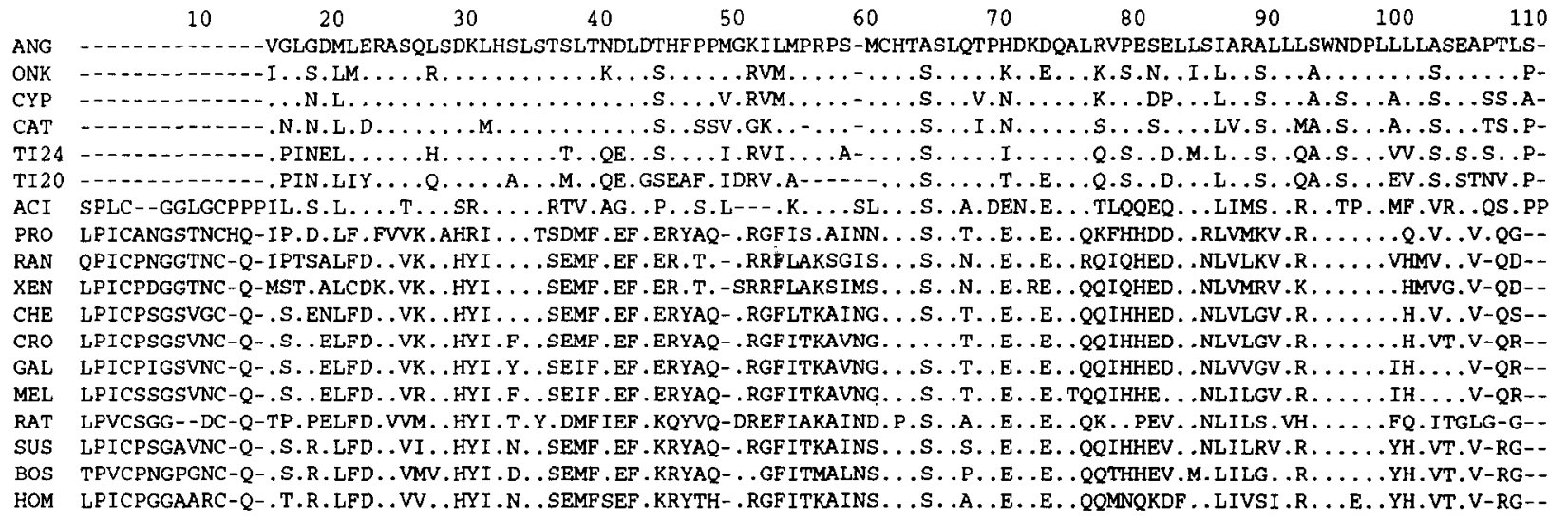

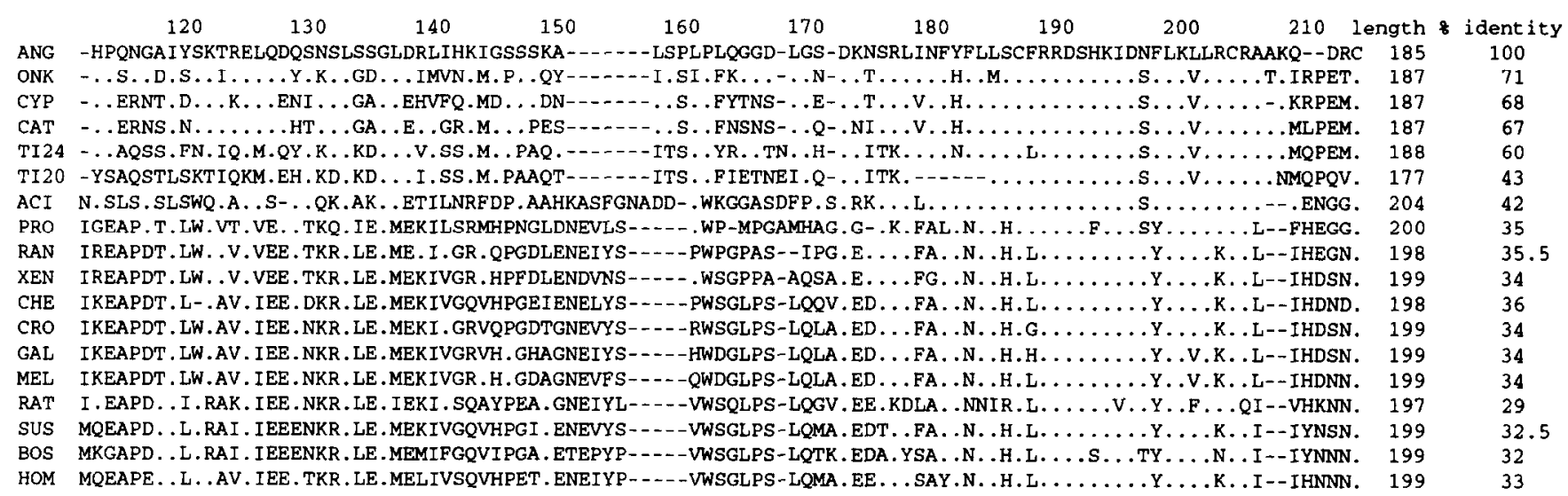

Fig. 2. Alignment of the sequences of prolactin from different representatives of vertebrates with the European eel (Ang) sequence. Dashes indicate deletions introduced for best alignment. Dots represent residues identical to the eel sequence. The percentages of homology with the eel sequence are indicated at the end of the sequences. The references used are: Cyp (Cyprinus carpio), Yasuda et al., 1987; Cat (Ictalurus punctatus), Watanabe et al., 1992; Ti24 and Ti20 (Oreochromis mossembicus $24 \mathrm{~K}$ and $20 \mathrm{~K}$ variants), Yamagushi et al., 1988); Onk (Oncorhynchus keta), Song et al., 1988; Aci (Acipenser gueldenstaedti) Noso et al., 1993); Pro (Protopterus sp.), Noso et al., in press; Ran (Rana catesbeiana) Takahashi et al., 1990; Xen (Xenopus laevis), Buckbinder L. and Brown D.D., unpublished, appeared in EMBL under L07620; Cro (Crocodylus novaeguineae), Noso et al., 1992); Gal (Gallus gallus domesticus), Hanks et al., 1989; Mel (Meleagris gallopavo), Karatzas et al., 1990; Rat (Rattus norvegicus), Cooke et al., 1980; Sus (Sus scrofa), Li et al., 1976; Bos (Bos taurus), Miller et al., 1981; Hom (Homo sapiens) Cooke et al., 1981. 


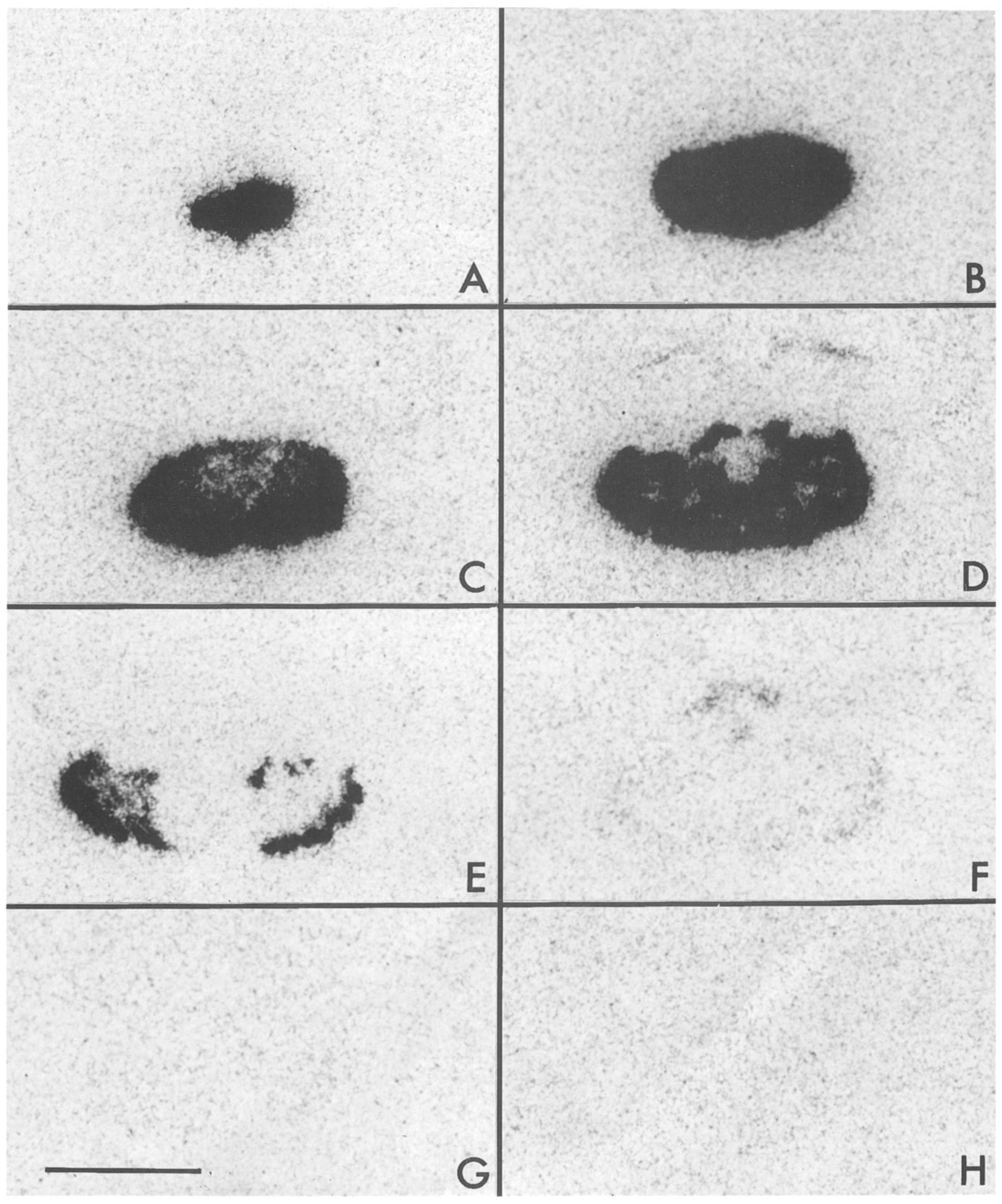

Fig. 3. Autoradiographs of selected transversal sections of the pituitary gland of freshwater silver eel, rostral to caudal (from $A$ to $F$; $G$ and $H$ are in the same region as C), hybridized either with the anti-sense prolactin RNA probe (A-G) or with the control sense prolactin RNA probe (H). Section $\mathrm{G}$ was treated with RNAse A prior to the hybridization. Exposure time: $24 \mathrm{~h}$. Scale bar $=1 \mathrm{~mm}$. 
the anti-sense prolactin RNA probe (Fig. 3A-C). When sections were taken from the region of the pituitary stalk, the signal is restricted to the periphery (Fig. $3 \mathrm{D}, \mathrm{E})$. No signal is detected in the posterior part of the pituitary gland (Fig. 3F). The specificity of the hybridization was confirmed by using the sense RNA probe (Fig. $3 \mathrm{H}$ ) or following pre-treatment with RNAse A prior to hybridization with the anti-sense probe (Fig. $3 G$ ) on anterior part sections (i.e. corresponding to the region of section $B$ ) where no signal is detected. Fig. 4 shows a bright-field micrograph of a section adjacent to section E of Fig. 3, hybridized with the prolactin antisense RNA probe. Grain-containing cells are organized in clusters of $50-100$ cells.

\subsection{Regulation of the eel prolactin pituitary $m R N A$ level in vivo}

Action of accommodation to sea water. Three weeks after the transfer of silver eels from freshwater to sea water, the mRNA levels of prolactin in the pituitary was lowered by approximately 5 -fold $(p<0.01)$ (Fig. 5 and Table 1).

Absence of action of the thyroid hormones. No effect was observed on the mRNA levels of prolactin in the pituitary 3 weeks after implantation of $500 \mu \mathrm{g}$ of either triiodothyronine or thyroxine (Table 2). Plasma levels of triiodothyronine $(2.9 \pm 0.2 \mathrm{ng} / \mathrm{ml}$ in controls $)$ reached $94 \pm 16 \mathrm{ng} / \mathrm{ml}$ in the $500 \mu \mathrm{g}$ triiodothyronine treated eels, and thyroxine was increased from $5.9 \pm 1.5$ to $94 \pm 45 \mathrm{ng} / \mathrm{ml}$ when implanted with thyroxine, without important modification of the triiodothyronine plasma level $(5.6 \pm 1.2 \mathrm{ng} / \mathrm{ml})$.

Absence of action of estradiol and testosterone. No significant effect of estradiol was observed whatever the dose used (between 20 and $500 \mu \mathrm{g}$ ) neither in the presence nor in the absence of testosterone at $500 \mu \mathrm{g}$, 2 weeks after implantation (Fig. 6). A significant difference $(p<0.05)$ was, however, observed between eels treated with $100 \mu \mathrm{g}$ of estradiol and those receiving testosterone in combination with this dose of estradiol. Plasma levels of estradiol $(0.22 \pm 0.03 \mathrm{ng} / \mathrm{ml}$ in controls) reached $8.2 \pm 0.3,34 \pm 1$, and $84 \pm 7 \mathrm{ng} / \mathrm{ml}$ in the 20,100 , and $500 \mu \mathrm{g}$ estradiol-treated eels, respectively. Testosterone plasma levels $(0.20 \pm 0.06 \mathrm{ng} / \mathrm{ml}$ in controls) reached $60-90 \mathrm{ng} / \mathrm{ml}$ in the $500 \mu \mathrm{g}$ testosterone treated eels, except with the highest dose of estradiol in which testosterone plasma level was only $29 \pm 4 \mathrm{ng} / \mathrm{ml}$ after 2 weeks. Three other experiments also showed that neither estradiol alone or in combination with testosterone were effective in significantly altering (enhancing or lowering) prolactin mRNA levels 2 or 3 weeks after implantation of $500 \mu \mathrm{g}$ of each steroid (data not shown).

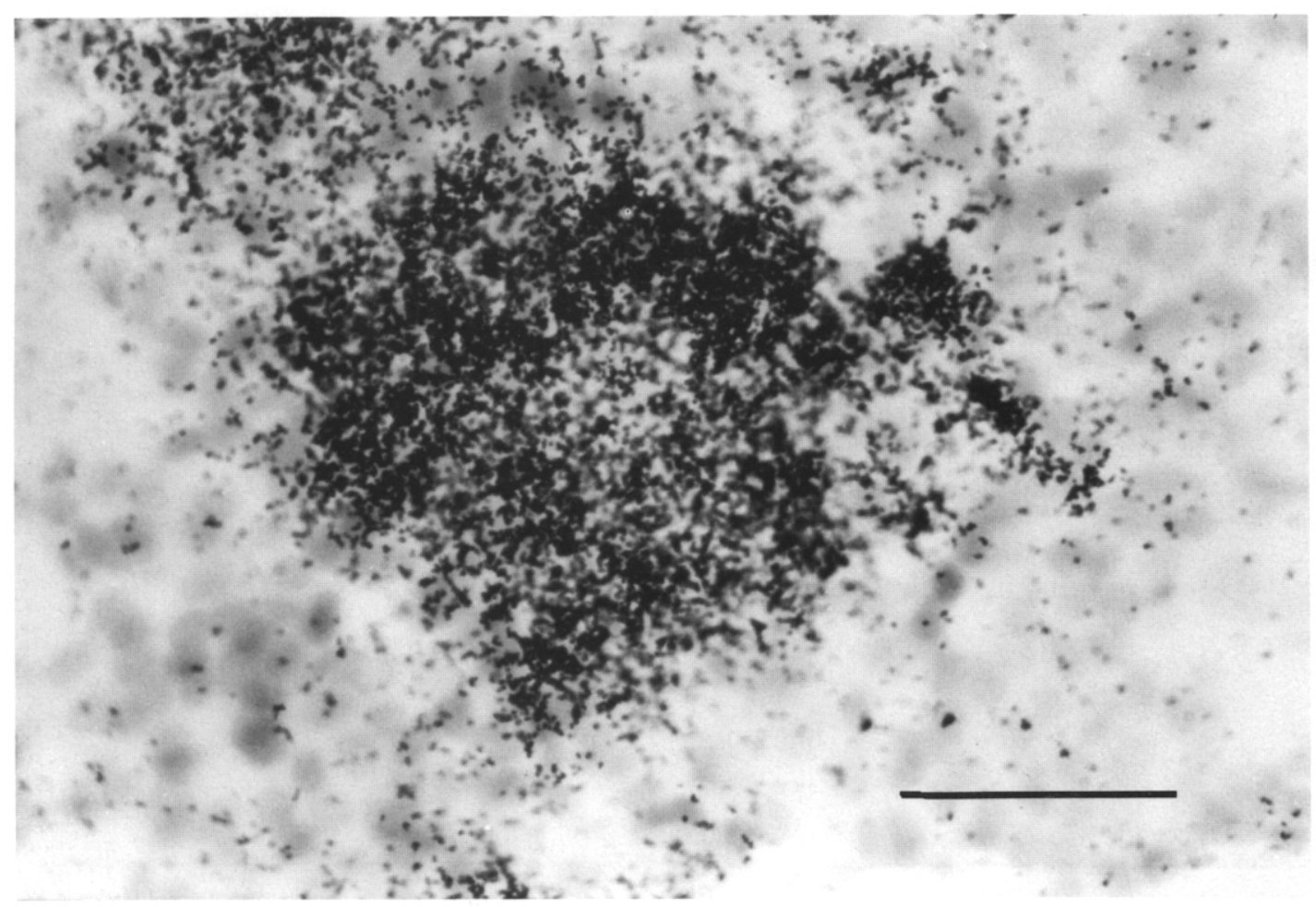

Fig. 4. Bright field micrograph of a section located in the rostral part of the pituitary gland (adjacent to section E of Fig. 3), hybridized with the anti-sense prolactin RNA probe. Exposure time: 3 days. Scale bar $=25 \mu \mathrm{m}$. 
Table 1

Effect of accommodation to sea water for 3 weeks on the pituitary mRNA level for prolactin

\begin{tabular}{lll}
\hline Nature of treatment & Freshwater & Sea water \\
\hline Prolactin mRNA/actin mRNA & $1.0 \pm 0.2$ & $0.2 \pm 0.04^{*}$ \\
\hline
\end{tabular}

Prolactin and actin mRNA levels were measured following Northern blot hybridization analysis (see Fig. 5) by scanning densitometry. The value of 1.0 was given to the control. Data are expressed as means \pm SEM of 6 individual values. ${ }^{*} \mathrm{P}<0.01$.

Time-course experiments with estradiol $(500 \mu \mathrm{g})$ in the presence of testosterone $(500 \mu \mathrm{g})$ failed to show any positive or negative correlation from day 0 to 10 weeks
Table 2

Effect of a 3 weeks treatment with triiodothyronine or thyroxine on the pituitary mRNA level for prolactin

\begin{tabular}{llll}
\hline Nature of treatment & 0 & $\begin{array}{l}\text { Triodo- } \\
\text { thyronine }\end{array}$ & Thyroxine \\
\hline Prolactin mRNA/actin mRNA & $1.0 \pm 0.15$ & $1.2 \pm 0.35$ & $0.75 \pm 0.2$
\end{tabular}

mRNA levels were measured following Northern blot hybridization analysis by scanning densitometry. The value of 1.0 was given to the control. Data are expressed as means \pm SEM of 6 individual values.

after implantation (Table 3). In this latter experiment, the values obtained for the pools of 5 pituitary glands were in the range of the values obtained using pools of

\section{Fresh water}

Sea water

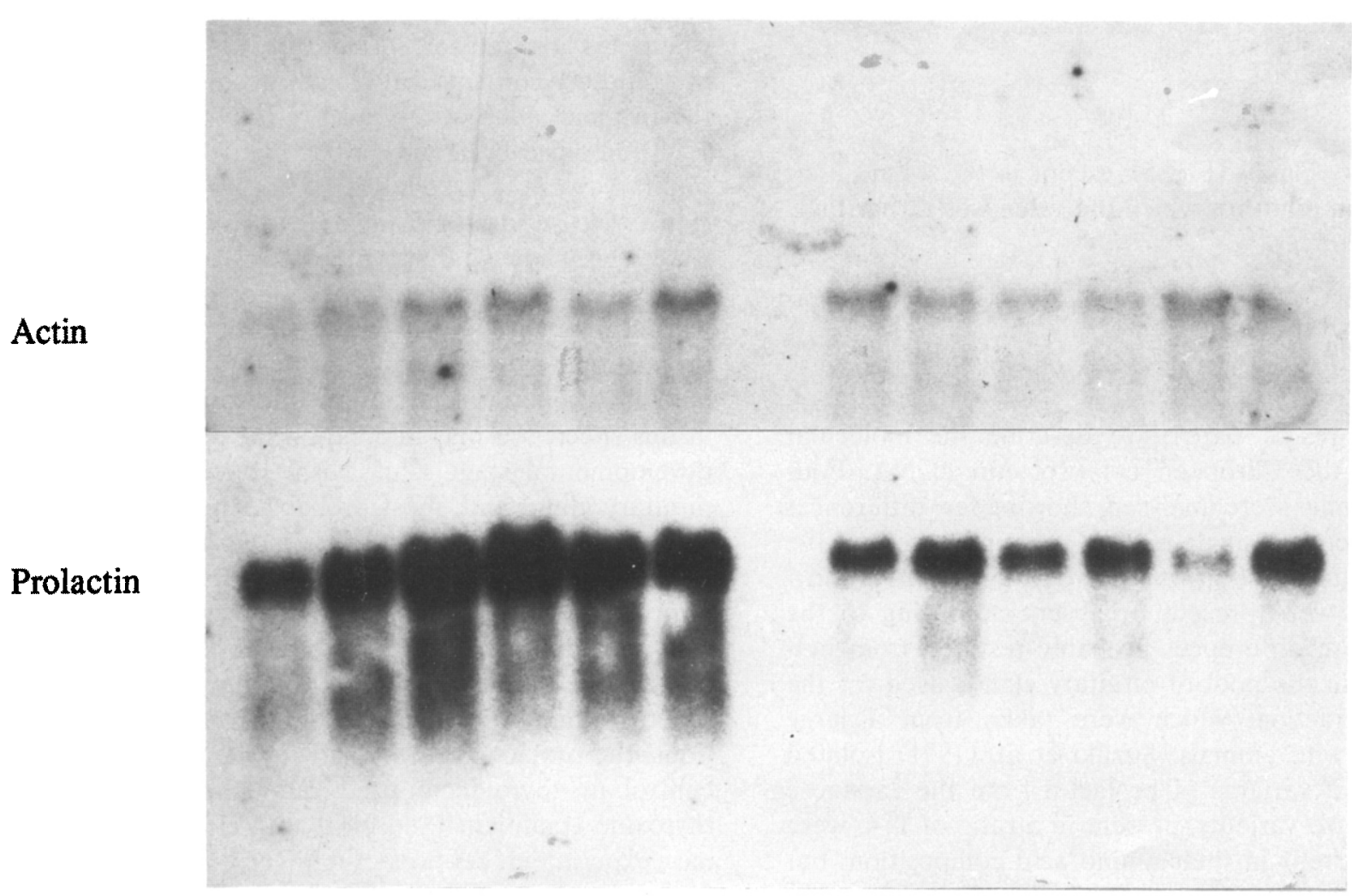

Fig. 5. Northern blot analysis of pituitary cytoplasmic RNA. 5 to $10 \mu \mathrm{g}$ total cytoplasmic RNA extracted from eels kept in freshwater (left panel) or accommodated to sea water for 3 weeks (right panel) were electrophoresed through a formaldehyde containing agarose gel and transferred to nylon membrane. The filter was successively hybridized with the eel prolactin cDNA probe (lower lane), and a trout actin cDNA probe (upper lane).

Table 3

Time course effect of treatment with estradiol + testosterone on the pituitary mRNA level for prolactin

\begin{tabular}{lllllll}
\hline Duration of testosterone + estradiol treatment & 0 & 4 days & 2 weeks & 4 weeks & 6 weeks & 10 weeks \\
\hline Prolactin mRNA/actin mRNA & 1.00 & 1.70 & 0.95 & 0.70 & 1.20 & 1.40 \\
\hline
\end{tabular}

Eels were killed at different time after implantation of $500 \mu \mathrm{g}$ each of testosterone and estradiol. mRNA levels were measured following Northern blot hybridization analysis by scanning densitometry. The value of 1.0 was given to the control. Data represent pools of 5 pituitary glands. 


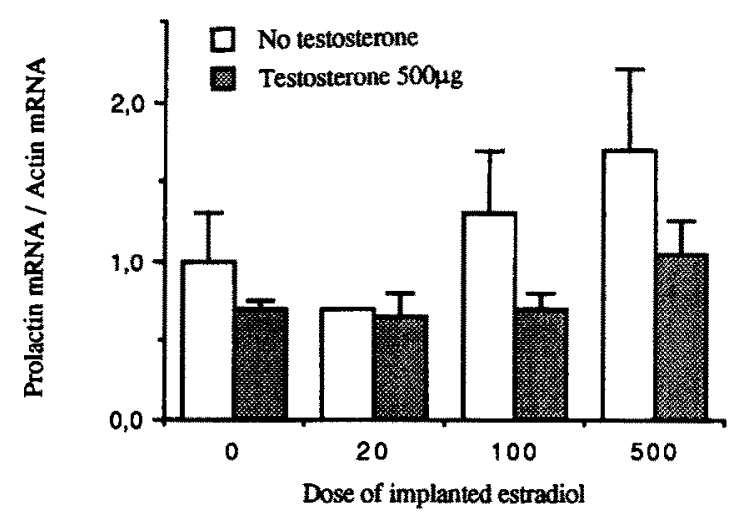

Fig. 6. Effect of different doses of estradiol together with or without testosterone, on pituitary mRNA level for prolactin. Estradiol and testosterone were administred as implants in coconut oil. Animals were killed two weeks after implantation. Prolactin and actin mRNA levels were measured as indicated in the legend of table 1. Data are expressed as means \pm SEM of three pools of two pituitary glands, except for the $20 \mu \mathrm{g}$ estradiol (without testosterone) point for which two pools, with identical values, were available.

two pituitary glands (Fig. 5), except in the 4 days after implantation point for which the value was rather high.

\section{Discussion}

In the present paper, we describe the molecular cloning of the European eel prolactin cDNA. Four different clones were analysed, showing few differences (all four encode a single mature protein), except in the $3^{\prime}$ untranslated portion where two fragments of 5 and 7 nucleotides were present or absent according to the clones. These differences probably resulted from heterogeneity in the pool of pituitary glands used for the mRNA extraction, which were taken from a large number of wild animals. Suzuki et al. (1991) isolated two different variants of prolactin from the Japanese eel. These two variants, present in a ratio of $1: 4$, were slightly different in their amino acid composition, but equipotent in biological activity. The first 57 amino acids sequenced for those two Japanese eel prolactins were identical and show only one difference with the European eel sequence (glycine instead of proline at position 54). In the European eel, only four different clones were sequenced and the possibility that another, rarer form, is present, cannot be excluded. However, the pattern of the Southern blot experiment is rather in favour of the presence of only one gene per haploid genome.

Comparison studies show that as for the other teleostean hormones (and also the holostean hormone: Dores et al., 1993), the eel prolactin lacks the $\mathrm{N}$-termi- nal disulphide bond that is present in all other vertebrates including the chondrostean sturgeon and the dipnoid lungfish. Highest homology scores are found with teleostean hormones (except with the short variant of tilapia), then in a decreasing order, with the sturgeon, a large group encompassing the lungfish, the amphibian reptilian and avian, and finally with the mammalian hormones.

The hybridization signal obtained with the prolactin RNA probe corresponds to the localisation in the rostral pars distalis as determined by immunocytochemistry using anti-eel prolactin serum in the Japanese eel pituitary gland (Suzuki et al., 1991).

Prolactin is believed to be the hormone responsible for the control of osmoregulation in freshwater fish (cf. Clarke and Bern, 1980; Hirano, 1986). Transfer of euryhaline and stenohaline fish from sea water to hypoosmotic water induces a marked stimulation of prolactin secretion (cf. Nishioka et al., 1988). Inversely, when eels are transferred from freswater to sea water, the pituitary content of prolactin declines, returning to the original value after 8 weeks (Hall and Chadwick, 1978). In our experiment, prolactin mRNA levels in the pituitary were markedly reduced three weeks after transfer to sea water compared to the levels in freshwater eels, showing that synthesis as well as secretion is reduced in response to hyperosmolarity. In the eel, prolactin release in vitro was shown to be inversely proportional to the osmolarity of the incubation medium (Ingleton et al., 1973), indicating that at least in this species (it may depend on the species or on the developmental stage - cf. Nishioka et al., 1988), the pituitary gland and, most probably, the prolactin cells are directly controlled by the osmolarity of the blood.

There is still no evidence for a role of thyroid hormones on prolactin synthesis or secretion in fish. In rats, the prolactin mRNA levels were enhanced compared to controls, $72 \mathrm{~h}$ after administration of triiodothyronine (Franklyn et al., 1987). In other conditions, the prolactin mRNA activity was stimulated over control or thyroidectomized rats 1 week after daily thyroxine treatment (Seo et al., 1979). In our preliminary experiment, eel prolactin mRNA levels were unaffected by 3 weeks treatment with thyroid hormone implants that increased circulating levels more that 20 -fold. These treatments did, however, lower pituitary mRNA level for $\alpha$ - and $\beta$-thyrotropin subunits (Salmon and Quérat, unpublished data), indicating that the doses and duration of treatment were compatible with physiological actions. However, these conditions might be inadequate for modulating prolactin gene expression. The first metamorphosis of the eel occurs in sea water, where the prolactin gene expression is expected to be low. A stimulatory action of the thyroid hormones on prolactin gene expression at the climax of this first metamorphosis, when the young eels are 
preparing to enter freshwater would be an advantage. It would thus be interesting to test the action of thyroid hormones in eels kept in sea water.

Another aspect of prolactin regulation is the contribution of the sexual steroids. Estradiol has been shown (i) to activate prolactin cells in Gillichtys mirabilis (Nagahama et al., 1975) and in the European eel (Olivereau and Olivereau, 1979; Olivereau et al,, 1986), (ii) to stimulate prolactin secretion from Oerochromis mossambica pituitary tissue culture (Barry and Grau, 1986), (iii) to stimulate prolactin synthesis but not release in the same species in similar conditions (Wigham et al., 1977), and (iv) to stimulate prolactin secretion without altering its synthesis in Clarias batrachus (Singh and Singh, 1981). These results show that the mechanism of action of estradiol on the prolactin gene expression might be complex and could depend on the species or the physiological state of the fish. In the experiments presented in this paper, there was no evidence that estradiol altered the eel prolactin mRNA level, whatever the dose used and the duration of treatment. These treatments were, however, adequate for selectively stimulating the pituitary mRNA levels for $\alpha$ - and $\beta$-subunits of the type 2 gonadotropin (Quérat et al., 1991a,b). The co-implantation of testosterone together with estradiol strongly potentiated the effect of estradiol on the gonadotropin mRNA levels, but did not modify prolactin mRNA levels. The lack of effect of estradiol on the prolactin pituitary mRNA levels was also reported in trout by Le Goff et al. (1992). In this latter case, the absence of a direct action of estradiol was attributed to a lack of discernible estradiol receptors in the prolactin cells as evidenced by in situ hybridization using a trout estradiol receptor RNA probe. Our results are in contrast with those previously reported in eels by Olivereau and coworkers (see above) in which an increased activity of the eel prolactin cells following estradiol treatment in vivo was observed using histological techniques. This increased activity could possibly solely reflect an activated secretion, independent of synthesis. Consequently, taken together, these results, tend to indicate that even if estradiol could stimulate the eel prolactin release from the prolactin cells, it does not stimulate de novo synthesis. Moreover, the gonadal maturation of the eel, with the expected increase in the gonadal steroid hormones, occurs during the reproductive migration across the ocean. If, as commonly admitted (see above), prolactin is implicated in osmoregulation in freshwater, but not in sea water, then levels of this hormones must be kept low during the reproductive migration of the eel. A stimulatory effect of gonadal steroids on prolactin production would be detrimental under these circumstances. Our results are then compatible with the physiological interpretation of the role of prolactin in osmoregulatory accommodation.

\section{Acknowledgements}

We thank Pr J. Martial and Dr F. Rentier-Delerue (Laboratoire de Biologie Moléculaire et de Génie Génétique, University of Liège, Belgium) and $\operatorname{Pr} \mathrm{Y}$. Valotaire (Laboratoire de Biologie Moléculaire, University of Rennes I, France) for providing the trout prolactin cDNA and the trout $\beta$-actin cDNA, respectively.

\section{References}

Barry, T.P. and Grau, E.G. (1986) Gen. Comp. Endocrinol. 62, 306-314.

Chang, Y.S., Huang, F.L. and Lo, T.B. (1992) Gen. Comp. Endocrinol. 87, 260-265.

Chao, S.C., Pan, F.M. and Chang, W.C. (1988) Nucleic Acids Res. $16,9350$.

Clarke, W.C. and Bern, H.A. (1980) in Hormonal Proteins and Peptides vol. 8 (Li, C.H., ed.), pp. 105-197, Academic Press, New York.

Cooke, N.E., Coit, D., Weiner, R.I., Baxter, J.D. and Martial, J.A. (1980) J. Biol. Chem. 255, 6502-6510.

Cooke, N.E., Coit, D., Shine, J., Baxter, J.D. and Martial, J.A. (1981) J. Biol. Chem. 256, 4006-4016.

Dessen, P., Fondrat, C., Valencien, C. and Mugnier, C. (1990) Comput. Appl. Biosci. 6, 355-356.

Dores, R.M., Noso, T., Rand-Wevear, M. and Kawauchi, H. (1993) Gen. Comp. Endocrinol. 90, 346-354.

Franklyn, J.A., Wood, D.F., Balfour, N.J., Ramsden, D.B., Docherty, K., Chin, W.W. and Sheppard, M.C. (1987), Endocrinology 120, 2279-2288.

Hall, T.R. and Chadwick, A. (1978) Gen. Comp. Endocrinol. 36, 388-395.

Hanks, M.C., Alonzi, J.A., Sharp, P.J. and Sang, H.M. (1989) J. Mol. Endocrinol. 2, 21-30.

Hirano, T. (1986) in Comparative Endocrinology: Developments and Directions (Ralph, C.L., ed.), pp. 53-74, A.R. Liss, New York.

Ingleton, P.M., Baker, B. and Ball, J.N. (1973) J. Comp. Physiol. 87, 317-328.

Karatzas, C, Zadworny, D. and Kuhnlein, U. (1990) Nucleic Acids Res. 18, 3071 .

Le Goff, P., Salbert, G., Prunet, P., Saligaut, C., Bjorsson, B.Th., Haux, C. and Valotaire, Y. (1992) Mol. Cell Endocrinol 90, 133-139.

Leloup, J. and de Luze (1980) C.R. Acad. Sci. Paris, série D 291, $87-90$.

Li, C.H. (1976) Int. J. Peptide Protein Res. 8, 205-224.

Mercier, L., Rentier-Delerue, F., Swennen, D., Lion, M., Le Goff, P., Prunet, P. and Martial, M. (1989) DNA 8, 119-125.

Miller, W.L., Coit, D., Baxter, J.D. and Martial, J.A. (1981) DNA 1, $37-50$.

Nagahama, Y., Nishioka, R.S., Bern, H.A. and Gunter, R.L. (1975) Gen. Comp. Endocrinol. 25, 166-188.

Nicoll, C.S., Mayer, G.L. and Russel, S.M. (1986) Endocr. Rev. 7, 169-203.

Nishioka, R.S., Kelley, K.M. and Bern, H.A. (1988) Zool. Sci. 5, 267-280.

Noso, T., Swanson, P., Lance, V.A. and Kawauchi, H. (1992) Int. J. Pept. Protein Res. 39, 250-257.

Noso, T., Nicoll, C.S., Polenov, A.L. and Kawauchi, H. (1993) Gen. Comp. Endocrinol. 91, 90-95.

Noso, T., Nicoll, C.S., and Kawauchi, H. (1994) Gen. Comp. Endocrinol, in press. 
Ono, M., Takayama, Y., Rand-Weaver, M., Sakata, S., Yasunga, T, Noso, T. and Kawauchi H. (1990) Proc. Natl. Acad. Sci. USA 87, 4330-4334.

Olivereau, M. and Olivereau, J. (1979) Gen. Comp. Endocrinol. 39, 247-261.

Olivereau, M., Dubourg, P., Chambolle, P. and Olivereau, J. (1986) Cell Tissue Res. 246, 425-437.

Quérat, B., Nahoul, K., Hardy, A., Fontaine, Y.A. and Leloup-Hatey, J. (1987) J. Endocrinol. 114, 289-294.

Quérat, B., Moumni, M., Jutisz, M., Fontaine, Y.A. and Counis, R. (1990) J. Mol. Endocrinol. 4, 257-264.

Quérat, B., Hardy, A. and Fontaine, Y.A. (1991a) J. Mol. Endocrinol. 7, 81-86.

Quérat, B., Hardy, A., Counis, R. and Fontaine, Y.A. (1991b) in Reproductive Physiology of Fish (Scott, A.P., Sumpter, J.P., Kim, D.E. and Rolfe, M.S., eds.), Fish Symposium 91, Sheffield.

Rand-Weaver, M., Noso, T, Muramoto, K. and Kawauchi, H. (1991) Biochemistry 30, 1509-1515.

Rentier-Delerue, F., Swennen, D., Prunet, P., Lion, M. and Martial, M. (1989) DNA 8, 261-270.

Sambrook, J., Fritsch, E.F. and Maniatis, T. (1989) in Molecular cloning: A Laboratory Manual, Cold Spring Harbor Press, Cold Spring Harbor, New York.
Singh, S.P. and Singh, T.P. (1981) Ann. Endocrinol. (Paris) 42, $57-62$.

Seo, H., Refetoff, S., Martino, E., Vassart, G. and Brocas, H. (1979) Endocrinology 104, 1083-1090.

Song, S., Trinh, K.Y., Hew, C.L., Wang, S.J., Belkhode, S. and Idler, D.R. (1988) Eur. J. Biochem. 172, 279-285.

Suzuki, R., Yasuda, A., Kondo, J., Kawauchi, H. and Hirano, T.(1991) Gen. Comp. Endocrinol. 81, 391-402.

Takahashi, N., Yoshihama, K., Kikuyama, S., Yamamoto, K., Wakabayashi, K. and Kato, Y. (1990) J. Mol. Endocrinol. 5, 281-287.

Watanabe, K., Igarashi, A., Noso, T., Chen, T.T., Dunham, R.A. and Kawauchi, H. (1992) Mol. Mar. Biol. Biotech. 1, 239-249.

Wigham, T., Nishioka, R.S. and Bern, H.A. (1977) Gen. Comp. Endocrinol. 32, 120-131.

Yamagushi, K., Speker, J.L., King, D.S., Yokoo, Y., Nishioka, R.S., Hirano, T. and Bern, H.A. (1988) J. Biol. Chem. 263, 9113-9121.

Yasuda, A., Itoh, H. and Kawauchi, H. (1986) Arch. Biochem. Biophys. 244, 528-541.

Yasuda, A., Miyazima, K.I., Kawauchi, H., Peter, R.E., Lin, H.R., Yamagushi, K. and Sano, H. (1987) Gen. Comp. Endocrinol. 66, 280-290.

Yasuda, A., Kawauchi, H. and Papkoff, H. (1990) Gen. Comp. Endocrinol. 80, 363-371. 